BioLink : Jurnal Biologi Lingkungan, Industri dan Kesehatan, Vol. 6 (1) Agustus (2019)

ISSN: 2356- 458X (print) ISSN: 2550-1305 (online)

DOI: 10.31289 /biolink.v6i1.2218

BioLink

Jurnal Biologi Lingkungan, Industri, Kesehatan

Available online http://ojs.uma.ac.id/index.php/biolink

\title{
UJI EFEKTIVITAS DAUN PANDAN WANGI (PANDANUS AMARYLLIFOLIUS ROXB.) SEBAGAI ANTIBAKTERI TERHADAP SALMONELLA TYPHI
}

\section{EFFECTIVENESS TEST OF PANDANUS AMARYLLIFOLIUS ROXB LEAVES EXTRACT AS ANTIBACTERIAL FOR SALMONELLA TYPHI}

\author{
Priska Nancy Claudia Bali*, Ahmad Raif, Setia Budi Tarigan \\ Program Studi Pendidikan Dokter, Fakultas Kedokteran, Universitas Prima Indonesia, \\ Indonesia
}

Diterima : 29-01-19; Disetujui : 26-04-19: Diterbitkan : 12-08-19

*Corresponding author: E-mail: prskcld@gmail.com

\begin{abstract}
Abstrak
Daun pandan wangi (Pandanus amaryllifolius roxb.) yang biasa digunakan sebagai bahan tambahan pada makanan mempunyai kandungan senyawa yaitu flavonoid, alkaloid, saponin dan tanin yang memiliki peran dalam aktivitas antibakteri. Penelitian ini dilakukan untuk menguji efektivitas antibakteri pada tumbuhan daun pandan wangi terhadap bakteri patogen salah satunya Salmonella typhi. Uji efektivitas antibakteri dari ekstrak etanol-etil asetat (1:1) daun pandan wangi ini menggunakan metode difusi cakram (disk diffusion) dengan membuat konsentrasi ekstrak 25\%, 50\%, $75 \%, 100 \%$. Hasil penelitian yang dilakukan menunjukkan bahwa ekstrak daun pandan wangi mempunyai efektivitas antibakteri terhadap bakteri Salmonella typhi dengan rata-rata diameter zona hambat yang terjadi sebesar 11,6 mm; $14 \mathrm{~mm}$; 14,3 mm; 15,3 mm; kontrol positif (Ciprofloxacin) 27 $\mathrm{mm}$; dan kontrol negatif (aquadest) tidak memiliki nilai untuk dapat menghambat pertumbuhan bakteri.
\end{abstract}

Kata Kunci: Pandanus Amaryllifolius Roxb, ekstrak, antibakteri, Salmonella typhi

\begin{abstract}
Pandanus amaryllifolius roxb leaves commonly used as food dditives which contain various compound groups namely alkaloid, saponins, flavonoids and tannins that have a role in antibacterial activity. This research is indicated to support the success of antibacterial in fragrant pandanus leaf plants against Salmonella typhi, one of the pathogenic bacteria. The antibacterial effectiveness test of ethanol-ethyl acetate extract (1: 1) of pandanus leaves which evaluated by the Kirby-bauer method and making the extract concentrations of $25 \%, 50 \%, 75 \%, 100 \%$. The results showed that pandanus leaves extract had antibacterial effectiveness against Salmonella typhi with an average inhibition zone diameter of $11.6 \mathrm{~mm}$; $14 \mathrm{~mm} ; 14.3 \mathrm{~mm} ; 15.3 \mathrm{~mm}$; positive controls (Ciprofloxacin) $27 \mathrm{~mm}$; and negative controls (aquadest) didn't produce the inhibition zone of Salmonella typhi.
\end{abstract}

Key Words: Pandanus Amaryllifolius Roxb, extract, antibacterial, Salmonella typhi

How to Cite: Bali, Priska, N.C., Raif, A., dan Tarigan, Setia. B.,, (2019). Uji Efektivitas Daun Pandan Wangi (Pandanus amaryllifolius roxb.) sebagai Antibakteri Terhadap Salmonella typhi, BioLink: Jurnal Biologi Lingkungan, Industri dan Kesehatan, Vol.6 (1): Hal. 65-72 
Bali, Priska, N.C., Raif, A., dan Tarigan, Setia. B. Uji Efektivitas Daun Pandan Wangi (Pandanus amaryllifolius roxb.) sebagai Antibakteri Terhadap Salmonella typhi

\section{PENDAHULUAN}

Penggunaan tumbuh-tumbuhan

sebagai obat dalam proses penyembuhan terhadap suatu penyakit adalah bentuk pengobatan yang tertua di dunia. Masingmasing budaya di dunia mempunyai sistem pengobatan yang khas dalam hal pengobatan tradisional dan di setiap daerah dijumpai berbagai macam jenis tumbuh-tumbuhan yang dapat dimanfaatkan sebagai bahan obat. Dalam prediksi WHO (World Health Organizations) pada tahun 1985 diketahui bahwa sekitar $80 \%$ penduduk yang ada di dunia telah memanfaatkan berbagai tumbuhan obat (herbal medicine, phytomedicine, phytotherapy, atau botanical medicine) dalam hal memelihara kesehatan primernya (Dorly, 2005).

Daun pandan wangi dikenal sebagai tanaman yang sering dimanfaatkan sebagai tambahan bahan makanan, pewarna dan juga dapat memberi aroma pada makanan. (Faras et al, 2014). Selain sebagai tambahan bahan makanan, daun pandan wangi (Pandanus amaryllifolius roxb.) diketahui memiliki kandungan senyawa yang terdapat didalamnya yang diduga memiliki potensi efektifitas antibakteri diantaranya yaitu senyawa flavonoida, alkaloid, saponin (Sukandar, 2008).. Kandungan senyawa kimia tersebut dinilai dapat menghambat pertumbuhan kanker, mikroba, menurunkan kadar glukosa darah dan sebagai antioksidan, bersifat antibiotik, serta menyebabkan terjadinya efek peningkatan kekebalan. (Prameswari dan Widjonarko, 2014).

Daun pandan wangi juga mempunyai beberapa aktivitas farmakologi berdasarkan bahan pelarut yang digunakan, yaitu sebagai antibakteri, antioksidan, antikanker, dan antidiabetik (Prameswari dan Widjanarko, 2014). Dari hasil-hasil penelitian yang terdahulu telah dilakukan terbukti bahwa penggunaan pelarut dalam melakukan ekstraksi senyawa berpotensi dalam mempengaruhi potensi terapi yang terjadi.

Terdapatnya kandungan senyawa flavonoid, saponin, tanin, polifenol, dan zat warna menjadi faktor penting dalam proses penghambatan pertumbuhan bakteri (Rumouw, 2017).

Penelitian ini dilakukan bertujuan untuk menguji efektivitas antibakteri dalam penggunaan ekstrak etanol-etil asetat (1:1) pada daun pandan wangi (Pandanus amaryllifolius roxb.) terhadap bakteri patogen Salmonella typhi serta konsentrasi yang dapat menghambat terjadinya pertumbuhan terhadap bakteri tersebut. Hasil penelitian ini diharapkan dasar dalam upaya pengembangan daun pandan wangi sebagai alternatif pengobatan herbal pada infeksi yang terjadi yang disebabkan oleh bakteri. 


\section{METODE PENELITIAN}

Penelitian ini merupakan jenis penelitian eksperimen laboratorium dengan metode difusi cakram. Sampel pada penelitian ini menggunakan daun pandan wangi, dan bakteri Salmonella typhi. Metode pengumpulan data dilakukan dengan cara random sampling. Penelitian ini menggunakan ekstrak dari tanaman daun pandan wangi yang diberi pelarut etanol-etil asetat (1:1). Untuk menentukan perbandingan jumlah dari bakteri yang hidup dilakukan pengukuran secara visual atau dilihat menggunakan jangka sorong.

Alat yang digunakan yaitu, lampu spiritus, kertas saring, gelas kimia, cawan petri, tabung reaksi, pipet tetes, rak tabung reaksi, hotplate stirrer, inkubator, kertas cakram, labu ukur, oven, blender, jangka sorong, beaker glass, batang pengaduk, pinset, cotton swab, neraca digital, rotary evaporator. Bahan yang digunakan dalam penelitian ini meliputi daun pandan wangi (Pandanus amaryllifolius roxb.), bakteri Salmonella typhi, Nutrient Broth (NB), Muller Hinton Agar (MHA), etanol 96\%, etil asetat, aquadest, antibiotik ciprofloxacin (sebagai kontrol positif), spiritus, plastic wrap, aluminium
Prosedur penelitian :

1. Persiapan Alat

Alat-alat yang akan digunakan dalam penelitian disterilisasi di autoklaf dengan suhu $121^{\circ} \mathrm{C}$ pada tekanan $1 \mathrm{~atm}$ dalam waktu 15 menit.

2. Pembuatan Ekstrak Daun Pandan Wangi Pembuatan ekstrak menggunakan daun pandan wangi. Daun yang telah dipetik dicuci dengan air yang mengalir hingga bersih, lalu diletakan pada suhu kamar dan tidak boleh terkena sinar matahari, dibiarkan selama seminggu hingga daun mengering dan mudah hancur lalu dihaluskan menggunakan blender. Bubuk daun pandan wangi kemudian di timbang sebanyak 500 gr, kemudian dimasukkan kedalam wadah lalu ditambahkan larutan etil asetat sebanyak 2,5 liter dan larutan etanol 96\% sebanyak 2,5 liter dengan perbandingan (1:1). Kemudian diaduk selama 30 menit untuk mencapai kondisi homogen. Selanjutnya larutan tersebut di maserasi selama 3-5 hari pada suhu kamar dengan setiap harinya diaduk selama 30 menit. Setelah 3-5 hari dilakukan filtrasi pada larutan dengan menggunakan penyaring. Hasil penyaringan dipekatkan dengan menggunakan alat rotary evaporator dengan suhu $50^{\circ} \mathrm{C}$ sampai ekstrak mengental.

3. Pembuatan Larutan Uji Berbagai Konsentrasi 
Bali, Priska, N.C., Raif, A., dan Tarigan, Setia. B. Uji Efektivitas Daun Pandan Wangi (Pandanus amaryllifolius roxb.) sebagai Antibakteri Terhadap Salmonella typhi

Hasil ekstraksi daun pandan wangi kemudian dibuat larutan sesuai dengan konsentrasi yang akan dipakai. Tiap konsentrasi yang akan digunakan adalah 100\%, 75\%, 50\%, dan 25\% (Sogandi et al, 2017). Aquadest digunakan sebagai kontrol negatif, antibiotik ciprofloxacin sebagai kontrol positif.

$$
\begin{array}{rl}
100 \%= & \frac{100 \mathrm{~g}}{100 \mathrm{~mL}} \times 10 \mathrm{~mL} \\
= & 10 \mathrm{~g} \text { ekstrak (murni) } \\
75 \% & \frac{75 \mathrm{~m}}{100 \mathrm{~mL}} \times 10 \mathrm{~mL} \\
= & 7,5 \mathrm{~g} \text { ekstrak larutkan } \\
& \text { dengan } 10 \mathrm{~mL} \text { aquadest } \\
= & \frac{50 \mathrm{~g}}{100 \mathrm{~mL}} \times 10 \mathrm{~mL} \\
= & 5 \mathrm{~g} \text { ekstrak larutkan } \\
& \text { dengan } 10 \mathrm{~mL} \text { aquadest } \\
= & \frac{25 \mathrm{~g}}{100 \mathrm{~mL}} \times 10 \mathrm{~mL} \\
25 \% & 2,5 \mathrm{~g} \text { ekstrak larutkan } \\
& \text { dengan } 10 \mathrm{~mL} \text { aquadest } \\
= & \begin{array}{l}
\text { Cakram antibiotik } \\
\text { ciprofloxacin }
\end{array} \\
= & \begin{array}{l}
\text { Cakram yang dicelupkan } \\
\text { ke dalam aquadest }
\end{array}
\end{array}
$$

4. Pembuatan Media Muller Hinton Agar (MHA)

Media MHA ditimbang sebanyak 34 gr kemudian dimasukkan ke dalam erlenmeyer 1000 ml, dilarutkan dengan $200 \mathrm{ml}$ aquadest yang steril, dipanaskan menggunakan hotplate stirrer hingga semua terlarut. Setelah itu, media MHA yang dibuat dalam erlenmeyer ditutup mulut gelasnya dengan menggunakan kertas aluminium foil lalu disterilkan dalam autoklaf dalam waktu 15 menit pada suhu $121^{\circ} \mathrm{C}$. Kemudian media dituangkan dalam cawan petri yang akan digunakan. Tunggu hingga menjadi padat. Cawan petri yang berisi media dibungkus kemudian di simpan dalam lemari pendingin.

\section{Pembuatan Media Nutrient Broth (NB)}

Media NB ditimbang sebanyak 8 gr kemudian dilarutkan dengan $100 \mathrm{ml}$ aquadest, lalu dipanaskan menggunakan hotplate stirrer hingga semua terlarut. Setelah itu, bahan yang telah homogen selanjutnya dibungkus menggunakan kertas aluminium foil lalu disterilkan dalam autoklaf selama 15 menit pada suhu $121^{\circ} \mathrm{C}$.

\section{Pembuatan Suspensi Salmonella typhi \\ Pembuatan suspensi dari bakteri} Salmonella typhi dengan cara dibiakkan pada media NB selama 24 jam. Koloni Salmonella typhi diambil satu ose lalu dimasukkan ke dalam tabung reaksi yang sudah berisi aquadest steril. Koloni bakteri kemudian dikocok sampai koloni tersebut halus dan tercampur dengan suspensi media hingga terlihat adanya kekeruhan. Kemudian setarakan dengan standar McFarland (McF) 0,5.

7. Uji Sensitivitas Antimikrobial Ekstrak Daun Pandan Wangi 
Uji antimikrobial menggunakan metode difusi cakram. Masing-masing cawan petri yang berisi media MHA yang sudah disterilkan di swab dengan mengguanakan cotton swab yang dicelupkan ke dalam suspensi bakteri yang berada dalam media NB. Lalu sebarkan atau ratakan sampai suspensi bakteri merata di keseluruhan permukaan media. Selanjutnya diletakkan diatas media yang telah dibagi dalam 2 bagian dengan konsentrasi masing-masing sampel $100 \%, 75 \%, 50 \%, 25 \%$ dengan volume $20 \mu \mathrm{l}$. Pada MHA lain diletakkan cakram yang berisi kontrol negatif (aquadest) dan kontrol positif (ciprofloxacin). Kemudian media diinkubasi dalam suhu $37^{\circ} \mathrm{C}$ selama \pm 48 jam lalu diamati pertumbuhan bakteri serta zona hambat yang terjadi. Zona hambat yang terbentuk diukur menggunakan jangka sorong.

8. Parameter Penelitian

Parameter yang diamati adalah diameter dari zona hambat yang terbentuk.
9. Metode Penelitian

Penelitian ini menggunakan uji metode difusi cakram dengan beberapa konsentrasi dari ekstrak daun pandan wangi $(100 \%, 75 \%, 50 \%$, dan 25\%), kontrol negatif (aquadest) dan kontrol positif (ciprofloxacin) dengan perlakuan yang diberikan sebanyak 3 kali pengulangan.

10. Analisa Data

Data hasil penelitian dihitung secara manual, kemudian data yang telah diolah tersebut disajikan ke dalam bentuk tabel.

\section{HASIL DAN PEMBAHASAN}

Efektivitas antibakteri ekstrak daun pandan wangi (Pandanus amaryllifolius roxb.) terhadap pertumbuhan Salmonella typhi dengan menggunakan uji sensivitas ditunjukkan dengan adanya aktivitas zona hambat atau disebut juga zona bening disekitar kertas cakram. Diameter zona hambat diukur menggunakan alat jangka sorong. Hasil penelitian dengan menggunakan konsentrasi 100\%, 75\%, $50 \%, 25 \%$ didapatkan zona hambat seperti yang tertera dalam Tabel berikut:

Tabel 1. Hasil Diameter Zona Hambat dari Ekstrak Daun Pandan Wangi (Pandanus amaryllifolius roxb.) sebagai Antibakteri terhadap Salmonella typhi dalam mm

\begin{tabular}{cccccc}
\hline & \multicolumn{5}{c}{ Diameter Zona Hambat (mm) } \\
Percobaan & \multicolumn{1}{c}{ Konsentrasi Ekstrak Daun Pandan Wangi } & $\mathrm{K}(+)$ \\
& $100 \%$ & $75 \%$ & $50 \%$ & $25 \%$ & 13 \\
I & 17 & 16 & 15 & 12 & 0 \\
III & 16 & 15 & 15 & 10 & 27 \\
Rata-rata & 13 & 12 & 12 & 11,6 & \\
\hline $\mathrm{K}(-)$ : Aquadest & 15,3 & 14,3 & 14 & &
\end{tabular}


Bali, Priska, N.C., Raif, A., dan Tarigan, Setia. B. Uji Efektivitas Daun Pandan Wangi (Pandanus amaryllifolius roxb.) sebagai Antibakteri Terhadap Salmonella typhi

Berdasarkan tabel diatas dapat dilihat bahwa hasil penelitian yang dilakukan dengan menggunakan ekstrak daun pandan wangi (Pandanus amaryllifolius roxb.) dengan pelarut aquadest sebagai antibakteri terhadap bakteri Salmonella typhi pada konsentrasi $100 \%, 75 \%, 50 \%, 25 \%$ dengan rata-rata diameter zona hambat dari 3 kali pengulangan, secara berturut-turut yaitu: $15,3 \mathrm{~mm} ; 14,3 \mathrm{~mm} ; 14 \mathrm{~mm} ; 11,6 \mathrm{~mm}$. Kontrol positif (ciprofloxacin), dan kontrol negatif (aquadest) membentuk zona hambat sebesar $27 \mathrm{~mm}$; dan $0 \mathrm{~mm}$ yang ditunjukkan dalam gambar diagram berikut ini:

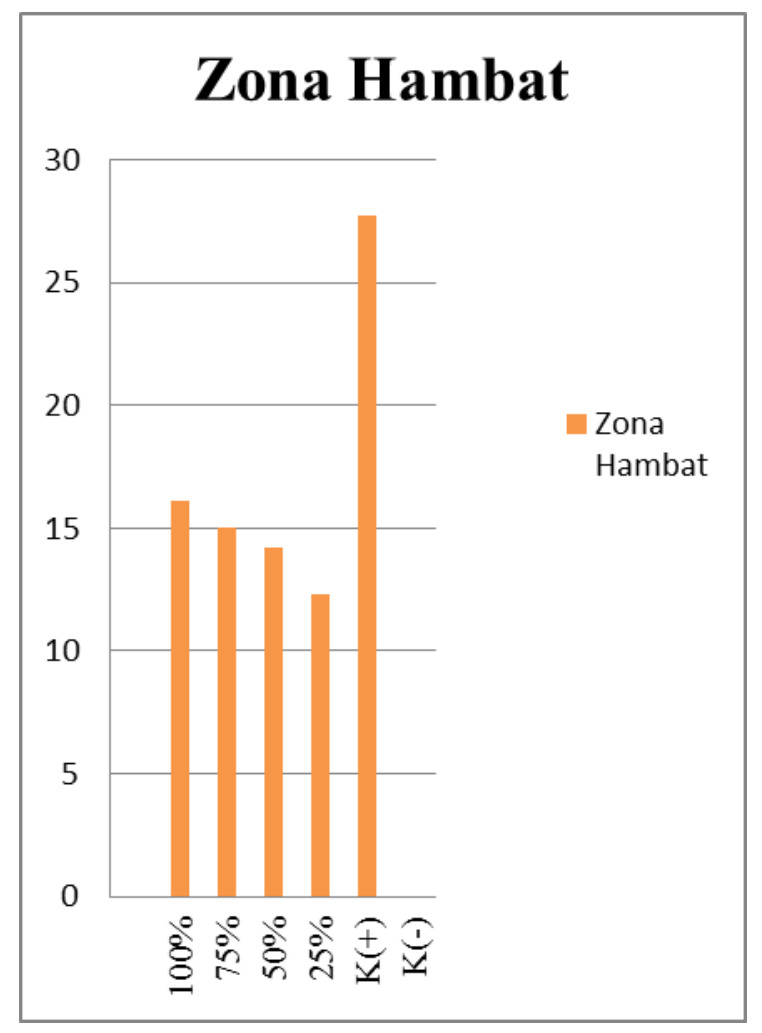

Gambar 1. Rata-rata zona hambat yang dibentuk oleh ekstrak daun pandan wangi, ciprofloxacin dan aquadest.
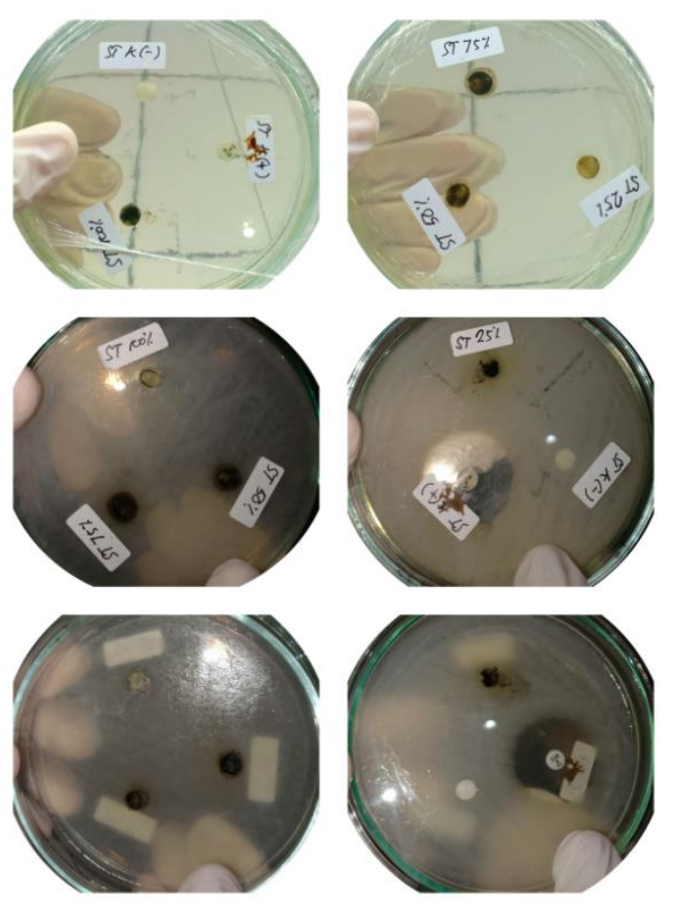

Gambar 2. Zona hambat jamur

Penelitian ini merupakan uji eksperimen laboratorium guna mengetahui ada tidaknya daya hambat yang dapat dinyatakan sebagai zona hambat dari ekstrak daun pandan wangi (Pandanus amaryllifolius roxb.) terhadap bakteri Salmonella typhi. Zona hambat adalah zona bening yang terdapat disekitar media yang telah diinokulasi bakteri. Aktivitas anti bakteri yang berupa zona bening ditimbulkan dari pemberian ekstrak dari tanaman daun pandan wangi (Pandanus amaryllifolius roxb.) terhadap bakteri Salmonella typhi yang disebabkan adanya kandungan senyawa-senyawa kimia yang terdapat didalamnya. Senyawa kimia tersebut yaitu flavonoid, alkaloid, polifenol, tanin, dan zat warna yang memiliki manfaat sebagai antibakteri. 
Hasil penelitian berdasarkan menghambat proses pertumbuhan bakteri. klasifikasi zona hambat Greenwood, (Bansode dan Chavan, 2012) (Rinawati, didapatkan bahwa ekstrak daun pandan 2010). Sifat sitotoksik yang dimiliki oleh wangi mempunyai efektifitas antibakteri saponin memampukan senyawa ini dalam terhadap bakteri pathogen Salmonella hal mempengaruhi permeabilitas dari typhi pada konsentrasi 100\%, 75\%, 50\%, membran sitoplasma sehingga sel mikroba $25 \%$ dengan rata-rata diameter zona lisis. (Ariana, D. 2017).

hambat adalah sebesar $15,3 \mathrm{~mm} ; 14,3$

Hasil penelitian sebelumnya mm; $14 \mathrm{~mm} ; 11,6 \mathrm{~mm}$. Daya hambat yang menunjukkan bahwa konsentrasi dari zat dimiliki ekstrak daun pandan wangi yang diberikan merupakan faktor penting (Pandanus amaryllifolius roxb.) terhadap yang dapat mempengaruhi efektivitas Salmonella typhi pada konsentrasi 100\% suatu zat. Semakin tinggi konsentrasi dari tergolong dalam kategori sedang, 75\% lemah, 50\% lemah dan 25\% lemah. Kontrol positif (Ciprofloxacin) pada Salmonella typhi tergolong dalam kategori kuat dengan nilai $27 \mathrm{~mm}$, sedangkan kontrol negatif (aquadest) tidak memiliki nilai untuk dapat menghambat pertumbuhan bakteri.

Daun pandan wangi terbukti mempunyai beberapa aktivitas pada farmakologi yaitu sebagai antibakteri, antidiabetes, antioksidan, dan juga antikanker. Hal itu bisa dibedakan berdasarkan ekstrak pelarutnya. Selain itu berbagai senyawa yang terkandung dalam daun pandan wangi (Pandanus amaryllifolius roxb.) memiliki peran tersendiri terhadap beberapa aktivitas tersebut. (Islamiaty, 2018)

Flavonoid merusak membran sel sampai tidak dapat terperbaiki dan mendenaturasi protein sehingga ekstrak tanaman daun pandan wangi, dan semakin tinggi kandungan bahan aktif yang berfungsi sebagai antimikroba, maka kemampuan untuk menghambat pertumbuhan bakteri juga semakin besar. (Mardiyaningsih, 2014).

\section{SIMPULAN}

Ekstrak daun pandan wangi (Pandanus amaryllifolius roxb.) memiliki efektivitas antibakteri terhadap pertumbuhan bakteri Salmonella typhi pada konsentrasi 100\%, 75\%, 50\%, dan 25\%. Rata-rata efek hambat yang paling besar terdapat pada konsentrasi 100\%.

\section{UCAPAN TERIMA KASIH}

Penulis mengucapkan banyak terimakasih kepada dr. Setia Budi Tarigan, Sp.S selaku dosen pembimbing yang sudah membantu mengarahkan selama penelitian serta dr. Ahmad Raif, M.Med.Ed selaku dosen penguji yang dalam hal ini 
Bali, Priska, N.C., Raif, A., dan Tarigan, Setia. B. Uji Efektivitas Daun Pandan Wangi (Pandanus amaryllifolius roxb.) sebagai Antibakteri Terhadap Salmonella typhi

telah membantu memberi saran dan masukkan yang baik dalam tugas jurnal ini.

\section{DAFTAR PUSTAKA}

Ariana, D. (2017). Pengaruh Perasan Daun Pandan Wangi (Pandanus amaryllifolius Roxb) Terhadap Shigella dysentriae. The Journal of Muhammadiyah Medical Laboratory Technologist, $\quad 1(1), \quad 67$. https://doi.org/10.30651/imlt.vii1.1010

Dorly. (2005). Potensi tumbuhan obat indonesia dalam pengembangan industri agromedisin. Makalah Pribadi Sekolah Pasca Sarjana Institut Pertanian Bogor, 1-10.

Faras, A. F., Wadkar, S. S., \& Ghosh, J. S. (2014). Effect of leaf extract of pandanus amaryllifolius (Roxb.) on growth of Escherichia coli and Micrococcus (Staphylococcus) aureus. International Food Research Journal, 21(1), 421-423.

Islamiaty, R. R., Halimah, E., Farmasi, F., Padjadjaran, U., Gamma, S., \& Beta, S. (2018). Farmaka Farmaka. 16, 222-230.

Mardiyaningsih, A., \& Aini, R. (2014). Pengembangan Potensi Ekstrak Daun Pandan ( Pandanus amaryllifolius Roxb ) Sebagai Agen Antibakteri Development Of Pandanus amaryllifolius Roxb Leaves Extract As Antibacterial Agent. Jurnal Kesehatan, volume 4(2), 185-192. https://doi.org/10.1016/i.theochem.2000.04. $\underline{025}$
M.D., B. D. S. and C. (2012). Studies on antimicrobial activity and phytochemical analysis of citrus fruit juices against selected enteric pathogens. International Research Journal of Pharmacy, 3(11), 122-126.

Prameswari, O. M., \& Widjanarko, S. B. (2014). The Effect of Water Extract of Pandan Wangi Leaf to Decrease Blood Glucose Levels and Pancreas Histopathology at Diabetes Mellitus Rats. Jurnal Pangan Dan Agroindustri, 2(2), 16-27.

Purwanti, N. U., Luliana, S., \& Sari, N. (2018). PENGARUH CARA PENGERINGAN SIMPLISIA DAUN PANDAN ( Pandanus amaryllifolius ) TERHADAP AKTIVITAS PENANGKAL. 1(2), 63-72.

Rinawati, N. D. (2010). Daya Antibakteri Tumbuhan Majapahit ( Crescentia cujete L .) Terhadap Bakteri Vibrio alginolyticus. Surabaya, 1-13. https://doi.org/10.1017/Sog59270000003142

Rumouw, D. (2017). IDENTIFIKASI DAN ANALISIS KANDUNGAN FITOKIMIA TUMBUHAN SEKITAR KAWASAN HUTAN LINDUNG SAHEDARUMAN ( Identification and Analysis of Natural Product Fitokimia Content the Drugs Use of the Community Around the Forest Protected Area Sahendaruman ). 4(November).

Sukandar, D., Hermanto, S., \& Lestari, E. (2008). Uji Toksisitas Ekstrak Daun Pandan Wangi (Pandanus amaryllifolius Roxb.) Dengan Metode Brine Shrimp Lethality Test (BSLT). Jurnal Kimia VALENSI, 1(2). https://doi.org/10.15408/ikv.v1i2.217 